\title{
Chapter 42 \\ Articles 42 and 44(6): Making \\ the Convention and States Parties' \\ Compliance Widely Known
}

\author{
Christian Whalen and Gerison Lansdown
}

Article 42

States Parties undertake to make the principles and provisions of the Convention widely known, by appropriate and active means, to adults and children alike.

Article 44(6)

States Parties shall make their reports widely available to the public in their own countries.

\section{Overview}

These two articles place obligations on States Parties regarding dissemination of information about the Convention. Article 42 demands that both adults and children must be informed about the rights in the Convention and its protocols. Rights holders must have knowledge of their rights and knowledge of how to exercise them if those rights are to be meaningful. Article 44(6) addresses the initial and periodic reports to the Committee on the Rights of the Child (the Committee) that States Parties are required to produce on progress in implementing the Convention and imposes an

\footnotetext{
C. Whalen $(\bowtie)$

Office of the Child, Youth and Seniors Advocate, Fredericton, NB, Canada

e-mail: Christian.Whalen@gnb.ca

G. Lansdown

Carleton University, Ottawa, ON, Canada

(C) The Author(s) 2022

Z. Vaghri et al. (eds.), Monitoring State Compliance with the UN Convention

on the Rights of the Child, Children's Well-Being: Indicators and Research 25,

https://doi.org/10.1007/978-3-030-84647-3_42
} 
obligation on States Parties to disseminate the reports widely. The Committee insists that its Concluding Observations be broadly disseminated by States Parties, to inform the public of the responses given by governments and ensure accountability in this regard (2003, para. 73).

In General Comment no. 5, the Committee sets out the principal requirements of States Parties in meeting their obligations under Article 42 and 44(6), together with its rationale. These include ensuring the visibility of children, enhancing respect for them and for democratic institutions, reaffirming the value of their rights, strengthening awareness among adults about children's rights, building accountability, and opening opportunity for debate (2003, paras. 66-73).

\section{General Principles}

Article 2 States Parties must make diligent efforts in their dissemination and educational programmes to reach all children (Sedletzki, 2013, p. 67), including marginalised children and youth. Every child, without discrimination on any grounds, has an equal right to knowledge about their rights (UN Committee on the Rights of the Child, 2001, para. 15). States Parties must adopt the necessary measures to ensure that children, including, for example, those who are out of school, street affected children, migrant, refugee, and asylum-seeking children as well as those living in conflict zones, are provided with accessible information on the Convention, including through non-formal and street education (UN Committee on the Rights of the Child, 2017, para. 55). Efforts to advance equality will be seriously diminished if Article 2 is not assiduously respected in the implementation of Article 42. Children cannot challenge discrimination without knowledge and understanding that they have the right to be treated equally and have knowledge of the actions states have taken in this regard.

Article 3 It is in the best interests of every child to know about their rights. States Parties must ensure that their dissemination and educational programmes are designed and delivered in a manner consistent with children's best interests and have their best interests as a primary concern. In addition, children's best interests need to inform the States Parties reports. Dissemination of the reports serves as a powerful accountability mechanism for child rights enforcement.

Article 6 Children are entitled to be informed about their right to life, survival, and development and this overarching principle needs to inform the approach taken to dissemination of the Convention and subsequent reports.

Article 12 The child's right to be heard and to have their opinions considered is critically important in the development of dissemination and educational programmes concerning children's rights. Furthermore, any education or awareness raising, both for children and adults, must include an explicit focus on children's participation rights and how this can be exercised. Children should be actively 
engaged in every aspect of child rights education programming from the ideation to the design stage right through to program delivery.

The Committee has developed Working Methods for the Participation of Children in the Reporting Process of the Committee on the Rights of the Child (2014a). The Treaty Specific Guidelines on States Parties reports also invites States Parties to take appropriate measures to consult and include opportunities for child participation both in the preparation of States Parties reports and the dissemination of the Committee's concluding observations.

\section{Articles Related or Linked to Articles 42 and 44(6)}

All the other substantive rights set out in the Convention are necessarily linked to Articles 42 and 44(6) because the obligation to educate others about child rights applies specifically with respect to each of those rights. For ease of reference however, only the other procedural rights from part II and the substantive rights in part I having a strong procedural connection to Articles 42 are identified here. ${ }^{1}$

Article 4 establishes the States Parties obligations to take all appropriate measures for full implementation of the rights guaranteed under the Convention.

Article 41 addresses the preservation of other rights guaranteed in other treaties or under domestic law.

Article 43 sets out the composition, role, and functions of the UN Committee on the Rights of the Child.

Article 44 sets out States Parties' obligation to make reports to the Committee on the Rights of the Child regarding the treaty's implementation.

Article 45 provides for international cooperation and establishes the role of UNICEF, UN organs, and others as technical experts in relation to child rights.

\section{Relevant Instruments}

International Covenant on Civil and Political Rights (1966), Article 2.

International Covenant on Economic, Social and Cultural Rights (1966), Article 2.

\footnotetext{
${ }^{1}$ For a more complete list of educational priorities related to child rights pursuant to Article 42 please refer to the original guidelines for periodic reports (UN Committee on the Rights of the Child, 1991). A helpful summary is provided in the Implementation Handbook (UNICEF, 2007, pp. 630-631).
} 


\section{Attributes}

\section{Attribute One: Making the Convention Widely Known}

Making both the principles and provisions of the Convention widely known, by appropriate and active means, requires dedicated resources by governments through coordinating mechanisms across government, educational systems, and the work of independent national human rights institutions and specialised institutions for children's rights. It requires cooperation and partnership between all these organizations and with civil society and the private sector (Sedletzki, 2013, p. 70). The Committee has consistently encouraged such measures in its General Comments and its Days of General Discussion (UN Committee on the Protection of the Rights of All Migrant Workers and Members of Their Families and UN Committee on the Rights of the Child, 2017, paras. 52-54; UN Committee on the Rights of the Child, 2016, para. 90, 2017, para. 62). ${ }^{2}$ However, the Committee has expressed concern over the continued lack of awareness of rights in many countries around the world. ${ }^{3}$ In a global survey of 1600 children on their civil and political rights, a strong message emerged of their demand for better information about their rights (Orr et al., 2016). Without knowledge of rights, it is not possible to exercise them. Accordingly, the Committee has placed special emphasis on incorporating learning about the Convention and human rights in general into the school curriculum at all stages (2003, para. 68). ${ }^{4}$

States Parties should engage the support of local and national media in disseminating information and news related to child rights awareness and education (UN Committee on the Rights of the Child, 2003, para. 70). The dissemination of States Parties reports reinforces education and understanding of children's rights. Furthermore, by learning what measures states have undertaken through the dissemination of their States Parties reports, children and adults will gain an enhanced understanding of their rights and implementation.

\section{Attribute Two: Educating Adults and Children Alike}

Child rights efforts will fail if the adults who nurture and care for children are not cognizant of their rights and familiar with their obligations as duty-bearers to children. Therefore, the Convention emphasises the need to educate both children

\footnotetext{
${ }^{2}$ Concluding observations to States Parties regularly reinforce this message on the need for dissemination of child rights information, including the Committee's concluding observations for Hungary (2020a, para. 48) and Austria (2020b, para. 48).

${ }^{3}$ See, for example, concluding observations for Hungary (2014b, paras. 15-16) and Rwanda (2020c, para. 12).

${ }^{4}$ See also Article 29.
} 
and adults about child rights (UN Committee on the Rights of the Child, 2003, para. 66). This education requires knowledge of rights and the extent to which they have or have not been implemented. States Parties need a comprehensive strategy to educate all of society about children's rights, but they need to adapt public education efforts to the distinct audiences based upon age. Child-friendly and youth-friendly versions of the Convention should be widely available in all national languages, in schools and in social media, libraries and online resources (UN Committee on the Rights of the Child, 2003, para. 67).

Pre- and post-training of professionals working with children needs to include the Convention, its implementation, and its implications for their work at all levels. Such training needs to 'emphasize the status of the child as a holder of human rights, to increase knowledge and understanding of the Convention and to encourage active respect for all its provisions' (UN Committee on the Rights of the Child, 2003, para. 53). Training on children's rights should include reference to States Parties reports and Concluding Observations. Specialised child rights training modules should be developed as orientation tools upon recruitment of all staff working directly with children or for children (UNICEF, 2007, pp. 629-630).

\section{References}

Orr, K., Emerson, L., Lundy, L., Royal-Dawson, L., \& Jimenez, E. (2016). Enabling the exercise of civil and political rights: The views of children. Save the Children. Retrieved from https:// resourcecentre.savethechildren.net/library/enabling-exercise-civil-and-political-rights-viewschildren

Sedletzki, V. (2013). Championing Children's rights: A global study of independent human rights institutions for children. Innocenti Publications. Retrieved from https://www.unicef-irc.org/ publications/701-championing-childrens-rights-a-global-study-of-independent-human-rightsinstitutions.html

UN Committee on the Protection of the Rights of All Migrant Workers and Members of Their Families \& UN Committee on the Rights of the Child. (2017). Joint General Comment No. 3 (2017) of the Committee on the Protection of the Rights of All Migrant Workers and Members of Their Families and No. 22 (2017) of the Committee on the Rights of the Child on the general principles regarding the human rights of children in the context of international migration, $C M W / C / G C / 3, C R C / C / G C / 22$. UN. Retrieved November 6, 2020, from http:// digitallibrary.un.org/record/1323014

UN Committee on the Rights of the Child. (1991). General guidelines regarding the form and content of initial reports to be submitted by States Parties under article 44, paragraph 1(a), of the Convention, October 30, 1991, CRC/C/5. Retrieved October 12, 2020, from https:// digitallibrary.un.org/record/137523? $\mathrm{ln}=\mathrm{en}$

UN Committee on the Rights of the Child. (2001). General Comment No. 1 (2001) Article 29 (1): The Aims of Education, April 17, 2001, CRC/GC/2001/1. Retrieved October 10, 2020, from https://digitallibrary.un.org/record/447223? $\mathrm{ln}=\mathrm{en}$

UN Committee on the Rights of the Child. (2003). General Comment No. 5 (2003) General measures of implementation of the Convention on the Rights of the Child (arts. 4, 42 and 44, para. 6), November 27, 2003, CRC/GC/2003/5. Retrieved October 12, 2020, from https:// digitallibrary.un.org/record/513415? $\mathrm{ln}=\mathrm{en}$ 
UN Committee on the Rights of the Child. (2014a). Working methods for the participation of children in the reporting process of the Committee on the Rights of the Child, CRC/C/66/2. UN. Retrieved December 1, 2020, from http://digitallibrary.un.org/record/785298

UN Committee on the Rights of the Child. (2014b). Concluding observations: Hungary, October 14, 2014, CRC/C/HUN/CO/3-5. Retrieved October 11, 2020, from https://digitallibrary.un.org/ record $/ 793888 ? \mathrm{ln}=\mathrm{en}$

UN Committee on the Rights of the Child. (2016). General Comment No. 20 (2016) on the implementation of the rights of the child during adolescence, December 6, 2016, CRC/C/GC/ 20. Retrieved October 12, 2020, from https://digitallibrary.un.org/record/855544? $\ln =$ en

UN Committee on the Rights of the Child. (2017). General Comment No. 21 (2017) on children in street situations, June 21, 2017, CRC/C/GC/21. Retrieved October 12, 2020, from https:// digitallibrary.un.org/record/1304490? $\mathrm{ln}=\mathrm{en}$

UN Committee on the Rights of the Child. (2020a). Concluding observations: Hungary, March 3, 2020, CRC/C/HUN/CO/6. Geneva: 2020-03-03: UN. Retrieved from http://digitallibrary.un. org/record/3862647

UN Committee on the Rights of the Child. (2020b). Concluding observations: Austria, March 6, 2020, CRC/C/AUT/CO/5-6 (p. 12). Geneva: 2020-03-06: UN. Retrieved from http:// digitallibrary.un.org/record/3862649

UN Committee on the Rights of the Child. (2020c). Concluding observations: Rwanda, February 28, 2020, $C R C / C / R W A / C O / 5-6$ (p. 16). Geneva: 2020-02-28: UN. Retrieved from http:// digitallibrary.un.org/record/3862645

UNICEF. (2007). Implementation handbook for the convention on the rights of the child (3rd ed.). : UNICEF. Retrieved September 21, 2020, from https://digitallibrary.un.org/record/620060? $\ln =\mathrm{en}$

Open Access This chapter is licensed under the terms of the Creative Commons Attribution 4.0 International License (http://creativecommons.org/licenses/by/4.0/), which permits use, sharing, adaptation, distribution and reproduction in any medium or format, as long as you give appropriate credit to the original author(s) and the source, provide a link to the Creative Commons license and indicate if changes were made.

The images or other third party material in this chapter are included in the chapter's Creative Commons license, unless indicated otherwise in a credit line to the material. If material is not included in the chapter's Creative Commons license and your intended use is not permitted by statutory regulation or exceeds the permitted use, you will need to obtain permission directly from the copyright holder.

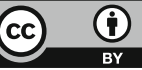

